\title{
AGAMA DALAM KEHIDUPAN INDIVIDU
}

\author{
Ahmad Taufik \\ STAI Bumi Silampari Lubuklinggau \\ ahmadtaufik201902@gmail.com
}

\begin{tabular}{|c|c|}
\hline & Abstrak \\
\hline $\begin{array}{l}\text { Article History } \\
\text { Received : 01-07-2019 } \\
\text { Revised : 03-07-2019 } \\
\text { Accepted : 09-07-2019 } \\
\text { Keywords : Religion, } \\
\text { Individual Life, Happy }\end{array}$ & $\begin{array}{l}\text { Religion as a form of human belief in } \\
\text { something supernatural or supernatural } \\
\text { turns out to be as if accompanying humans } \\
\text {-in the broad scope of life. Religion has } \\
\text { values for human life as people per person } \\
\text { and in relation to social life. Besides that } \\
\text { religion also has an impact on everyday } \\
\text { life. The influence of religion in an } \\
\text { individual's life is to give inner stability, } \\
\text { feeling of happiness, feeling of protection, a } \\
\text { sense of success and satisfaction. This } \\
\text { positive feeling will further be a motivator } \\
\text { to do religion in the life of an individual } \\
\text { besides being a motivation and ethical } \\
\text { value is also hope. }\end{array}$ \\
\hline
\end{tabular}

\section{Pendahuluan}

Berdasarkan hal tersebut, Seorang sosiolog agama bernama Elizabeth Nottingham berpendapat bahwa agama bukan sesuatu yang dapat dipahami melalui definisi, melainkan melalui deskripsi atau penggambaran. Tak ada satu pun definisi tentang agama yang benarbenar memuaskan.

Menurut gambaran Elizabeth Nottingham mengatakan agama adalah gejala yang begitu sering terdapat dimana-dimana dan agama berkaitan dengan usaha-usaha manusia untuk mengukur dalamnya makna dari keberadaan diri sendiri dan keberadaan alam semesta. Selain itu agama dapat membangkitkan kebahagiaan batin yang paling sempurna, dan juga perasaan takut dan ngeri. Meskipun 
perhatian tertuju kepada adanya suatu dunia yang tak dapat dilihat berupa akhirat.

\section{Metode Penelitian}

Metode yang digunakan dalam tulisan ini bersifat deskriptif kualitatif yang bertujuan untuk mendeskripsikan tentang sejarah Islam di bidang pendidikan. Dengan cara mencatat, menganalisis dan menginterpretasikannya bertujuan untuk memperoleh informasi yang dibutuhkan. jenis penelitian adalah studi literatur merupakan penelitian dengan mengumpulkan data yang diperlukan dari literaturliteratur yang berkaitan.

\section{Pembahasan}

\section{Manusia dan Agama}

Agama sebagai bentuk keyakinan manusia terhadap sesuatu yang bersifat adikodrati atau supernatural ternyata seakan-akan menyertai manusia dalam ruang lingkup kehidupan yang luas. Agama memiliki nilai-nilai bagi kehidupan manusia sebagai orang per orang maupun dalam hubungannya dengan kehidupan bermasyarakat. Melalui nilai agama juga memberi dampak positifdalam perilaku kehidupan sehari-hari. Dengan demikian secara psikologis, agama dapat berfungsi sebagai motif intrinsik atau dalam diri seseorang dan motif pembentuk kata hati. Namun agama melibatkan dirinya dalam masalah-masalah kehidupan keseharian di alam dunia (Elizabeth Nottingham, 1985: 4). Kata hati menurut Erich Fromm adalah panggilan kembali manusia kepada dirinya. Shaftesbury mengasumsikan kata hati sebagai suatu rasa moral dalam diri pribadi manusia berupa rasa benar dan rasa salah, reaksi emosional yang didasarkan atas fakta bahwa pikiran manusia pada dirinya sendiri dalam mengatur keharmonisan dirinya dengan tatanan kosmik. Boleh dikatakan bahwa filsafat skolastik atau filsafat agama lebih tegas menjadikan kata hati sebagai kesadaran akan prinsip-prinsip moral (Erich Fromm, 1988: 111).

Erich Fromm membagi kata hati menjadi: pertama, kata hati otoritarian yakni kata hati dibentuk oleh pengaruh luar diri manusia. Kedua, kata hati humanistik yakni kata hati yang bersumber dari dalam diri manusia tersebut. Kata hati humanistik adalah pernyataan 
kepentingan diri dan integrasi manusia, sedangkan kata hati otoritarian berkaitan dengan kepatuhan, pengorbanan diri dan tugas manusia atau penyesuaian sosialnya. Erich Fromm melihat manusia sebagai makhluk yang secara individu telah memiliki potensi humanistik dalam dirinya. Kemudian selain itu individu juga menerima nilai-nilai bentukan dari luar pribadi manusia. Keduanya membentuk kata hati dalam diri manusia, adapun apabila keduanya berjalan seiring secara harmonis maka manusia akan merasa bahagia.

Dalam melukiskan mengenai peran kata hati itu Erich Fromm menampilkan contoh cerita novel yang berjudul pemeriksaan pengadilan.Cerita itu mengungkapkan rasa bersalah seorang manusia yang dipersalahkan oleh otoritas yang tak tampak. Pendekatan psikoanalisis yang dikemukakan oleh Erich Fromm memberi pemahaman bahwa adanya fitrah manusia sebagai bentuk kesucian setiap individu. Bedanya, jika Erich Fromm melihat bahwa kata hati humanistik itu terbentuk berdasarkan latar belakang sejarah kemanusiaan, maka pendekatan agama secara Islami melihat naluri fitrah kesucian sebagai anugerah. Dalam diri manusia terdapat berbagai kreativitas untuk memberi arah dalam menjalani antar manusia. Potensi tersebut adalah 1) hidayat al-ghariziyyat 2) hidayat al-hissiyatt (inderawi) 3) hidayat al- aqliyyat (nalar), dan 4) hidayat al-diniyyat (agama). Melalui pendekatan ini, maka agama membawa sifat keterkaitan secara naluri yang dibawa sejak lahir. Pengaruh lingkungan terhadap seseorang adalah memberi bimbingan kepada potensi yang dimilikinya itu. Dengan demikian, jika potensi fitrah itu dapat dikembangkan sejalan dengan pengaruh lingkungan maka akan menjadi keselarasan. Sebaliknya jika potensi itu dikembangkan dalam kondisi yang dipertentangkan oleh kondisi lingkungan maka akan terjadi ketidak seimbangan pada diri seseorang.

Berdasarkan pendekatan ini, maka aspek agama dalam pribadi individu adalah memberi rasa batin, rasa bahagia, rasa terlindung, rasa sukses dan rasa puas atas hidup yang dialami. Perasaan positif ini menjadi pendorong untuk berbuat atau praktek agama dalam kehidupan individu selain menjadi motivasi dan nilai etik juga merupakan harapan. Agama membawa fungsi sebagai motivasi dalam mendorong individu untuk melakukan suatu aktivitas, karena perbuatan yang dilakukan dengan latar belakang keyakinan agama dinilai mempunyai unsur kesucian serta ketaatan. Keterkaitan ini akan memberi pengaruh diri seseorang untuk berbuat sesuatu. 
Sedangkan agama sebagai nilai etik karena dalam melakukan suatu tindakan akan perbuatanmanusia akan terikat kepada ketentuan antara yang tidak dianjurkan dan mana yang tidak boleh dilakukan menurut ajaran agama yang dianutnya.

Sebaliknya agama juga sebagai pemberi harapan bagi pelakunya. Manusia yang melakukan ajaran sesuai perintah agama umumnya karena adanya suatu harapan atau keyakinan tentang pengampunan atau kasih sayang diri sesuatu yang ghaib atau supernatural. Motivasi mendorong seseorang untuk berkreasi, berbuat kebajikan ataupun berkorban. Sedangkan nilai etik membawa aspek seseorang untuk berlaku jujur, menepati janji, menjaga amanat dan lain sebagainya. Sedangkan harapan mengharuskan pribadi seseorang untuk bersikap ikhlas, menerima cobaan yang berat ataupun berdoa. Sikap seperti itu akan lebih terasa secara mendalam jika bersumber dari keyakinan terhadap agama.

\section{Fungsi agama dalam kehidupan}

Dalam realita keadaan masyarakat mengenai sistem organisasi keagamaan merupakan organisasi formal yang mempunyai tenaga profesional tersendiri. Walaupun agama masih memberikan arti dan ikatan kepada sistem nilai dalam sistem kejadian masyarakat, namun pada saat yang sama lingkungan yang dianggap sakral dan yang sekuler masih dapat dibedakan. Agama sudah tidak sepenuhnya menyusup dalam aktivitas atau kegiatan yang terjadi pada masyarakat. Walaupun masih ada anggapan fakta bahwa agama dapat dijadikan sikap secara universal dan lebih tinggi dari norma-norma sosial sehari-hari pada umumnya (Elizabeth: 56). Nilai-nilai keagamaan dalam masyarakat tipe ini memaparkan fokus utamanya pada pengintegrasian perbuatan manusia dan pembentukan citra pribadi yang baik. Elizabeth berpendapat bahwa walaupun tidak sekental masyarakat tipe pertama, maka pada masyarakat tipe kedua ini agama ternyata masih difungsikan dalam kehidupan masyarakat. Namun terlihat ada kecenderungan adanya keyakinan tentang agama kian bergeser ke pembentukan sikap individu.

Kemudian pada masyarakat industri sekuler, organisasi keagamaan terpecah-pecah dan bersifat majemuk. Dia melihat di lingkungan masyarakat modern yang kompleks ini, ikatan antara terorganisasi keagamaan dan pemerintahan duniawi tidak ada sama 
sekali. Karena itu, agama cenderung dinilai sebagai bagian dari kehidupan manusia yang berkaitan dengan persoalan akhirat, sedangkan pemerintahan berhubungan dengan kehidupan duniawi. Elizabeth melihat gejala kehidupan keagamaan dalam masyarakat modern ini adalah masyarakat Amerika. Sejak sekitar tahun 1950-an, masyarakat terdiri atas mereka yang masuk ke dalam organisasi keagamaan yang jumlahnya cukup banyak, baik besar maupun kecil. Antar organisasi keagamaan itu terjadi persaingan karena itu tidak mengherankan jika ada warga masyarakat yang tidak ikut menjadi anggota dari salah satu organisasi keagamaan yang ada. Mereka disebut sebagai anggota gereja di atas kertas. Dalam masyarakat industri sekuler ini Elizabeth mengemukakan ciri-ciri khusus tersebut mengandung implikasi ganda bagi fungsi agama. Pertama, perbedaan bidang agama dan pertumbuhan sekularisme menimbulkan sikap toleransi terhadap perbedaan agama yang cukup tinggi. Kedua, keyakinan dan pengamalan keagamaan menjadikan agama sebagai pemersatu lingkungan organisasinya, khususnya bagi masyarakat minoritas.

Terlepas dari bentuk prioritas antara agama dengan masyarakat, baik dalam bentuk organisasi maupun fungsi intrinsik agama, maka yang jelas dalam keadaan masyarakat agama masih tetap memiliki fungsi dalam kehidupan masyarakat. Agama sebagai anutan masyarakat, terlihat masih berfungsi sebagai pedoman yang dijadikan sumber untuk menjalankan rona proses kehidupan.

Masalah agama tidak akan mungkin dapat disimpangkan dari roda kehidupan masyarakat, karena agama itu sendiri ternyata dijadikan pedoman dalam kehidupan bermasyarakat. Dalam prakteknya, fungsi agama dalam masyarakat antara lain:

\section{Fungsi edukatif}

Para penganut agama berpendapat bahwa norma agama yang mereka anut memberikan ajaran-ajaran yang harus dipatuhi. Ajaran agama secara yuridis berfungsi menyuruh dan melarang. Kedua unsur menyuruh dan larangan ini mempunyai latar belakang mengarahkan bimbingan agar pribadi penganutnya menjadi baik dan terbiasa dengan yang baik menurut ajaran agama masing-masing antar manusia. 


\section{Fungsi penyelamat}

Dimana pun manusia berada dia selalu ingin agar dirinya sendiri bisa mendapatkan selamat. Keselamatan yang meliputi bidang yang luas adalah keselamatan yang diajarkan oleh agama. Keselamatan yang meliputi dua alam yakni alam dunia maupun alam akhirat. Dalam mencapai keselamatan ini agama mengajarkan para penganutnya melalui pengenalan atau pemahaman awal kepada masyarakat sakral, berupa keimanan kepada Tuhan. Pelaksanaan pengenalan kepada unsur (zat supernatural) itu bertujuan agar dapat berkomunikasi baik secara langsung maupun dengan perantara langkah menuju ke arah itu secara praktisnya dilaksanakan dengan berbagai cara sesuai dengan ajaran agama itu sendiri, antaranya:

1) Theophania spontanea. Kepercayaan bahwa Tuhan dapat dihadirkan dalam benda-benda tertentu tempat angker, gunung, arca, dan lainnya.

2) Theophania innocativa. Kepercayaan bahwa Tuhan hadir dalam lambang karena dimohon, baik melalui invocative magis berupa magis atau dukun, maupun invocative religius berupa permohonan, doa, kesaktian, dan sebagainya.

Fungsi sebagai perdamaian

Melalui agama seseorang yang bersalah atau menganggap perbuatan berdosa dapat mencapai kedamaian batin melalui tuntunan agama. Bisa berdosa dan rasa bersalah akan segera menjadi hilang dari batinnya apabila seseorang pelanggar telah menebus dosanya melalui taubat, pensucian, atau penebusan dosa dengan bentuk lain.

\section{Fungsi sebagai social control}

Para penganut agama sesuai dengan ajaran agama yang dipeluknya terkait sifat batin kepada tuntunan ajaran tersebut, baik pribadi maupun antar kelompok. Ajaran agama oleh penganutnya dianggap sebagai norma, sehingga dalam hal ini agama dapat berfungsi sebagai pengawasan secara individu maupun secara kelompok karena agama merupakan instansi dan secara dogmatis mempunyai fungsi kritis yang bersifat profetis (wahyu, kenabian).

\section{Fungsi sebagai pemupuk rasa solidaritas}

Para penganut agama yang sama secara psikologis akan merasa memiliki kesamaan dalam satu kesatuan: keimanan, dan kepercayaan. 
Rasa kesatuan ini akan membina rasa solidaritas dalam kelompok maupun perorangan, bahkan kadang-kadang dapat membina rasa persaudaraan yang kokoh. Pada beberapa agama rasa persaudaraan itu bahkan dapat mengalahkan rasa kebangsaan.

\section{Fungsi transformative}

Ajaran agama dapat mengubah kehidupan pribadi manusia atau antar kelompok menjadi kehidupan baru sesuai dengan ajaranaagama yang dianutnya. Kehidupan baru yang diterimanya berdasarkan ajaran agama yang dipeluknya itu kadangkala mampu mengubah kesetiaanya kepada adat atau norma kehidupan yang dianutnya sebelum itu.

\section{Fungsi kreatif}

Ajaran agama mendorong dan mengajak para penganutnya untuk kerja produktif bukan saja untuk kepentingan dirinya sendiri, tetapi juga untuk kepentingan orang lain. Penganut agama bukan saja disuruh bekerja secara rutin dalam pola hidup yang sama, akan tetapi juga dituntut untuk melakukan inovasi dan penemuaan baru.

\section{Fungsi sublimatif}

Ajaran agama mengkuduskan segala usaha manusia, bukan saja yang bersifat agama ukhrawi, melainkan juga yang bersifat duniawi. Segala bentuk usaha manusia selama tidak bertentangan dengan norma-norma agama, jika dilakukan atas niat yang tulus, karena, hanya dan untukAllah merupakan ibadah.

\section{Agama dan spiritualitas}

Spiritual, spiritualitas, dan spiritualisme mengacu kepada kosakata latin spirit atau spiritus yang berarti napas. Adapun kata kerja spirare yang berarti untuk bernapas. Berangkat dari pengertian etimologis ini, maka arti spesifik untuk hidup adalah untuk bernapas, dan memiliki napas artinya memiliki spirit (Purwakania Hasan, 2006: 288). Spirit dapat juga diartikan kehidupan, nyawa, jiwa, dan napas (Hasan Shadiliy, 1984: 34). Dalam pengertian yang lebih luas spirit dapat diartikan sebagai: 1) kekuatan kosmis yang memberi kekuatan kepada manusia, 2) makhluk immateriil seperti peri, hantu, dan lain sebagainya, 3) sifat kesadaran, kemauan, dan kepandaian yang ada dalam alam menyeluruh, 4) jiwa luhur dalam alam yang bersifat 
mengetahui semuannya, mempunyai akhlak tinggi, menguasai keindahan, dan abadi, 5) dalam agama mendekati kesadaran ketuhanan, 6) hal yang terkandung dalam minuman keras, dan menyebabkan mabuk (Hasan Shadiliy, 1984: 40). Memang spiritualitas memiliki ruang lingkup dan pengertian yang luas. Menurut Purwakania Hasan mengatakan bahwa hasil penelitian Matsolf dan Mickey tentang sejumlah kata kunci yang mengacu kepada pengertian spiritualitas, yakni makna (meaning), nilai-nilai (values), transedensi (transcedency), bersambungan (connecting), dan menjadi (becoming).

Memang tampaknya pengertian spiritualitas merangkum sisisisi kehidupan rohani dalam dimensi yang cukup luas. Secara garis besarnya spiritualitas merupakan kehidupan rohani (spiritual) dan perwujudannya dalam cara berfikir, merasa baik, merasa berdoa, dan berkarya. Seperti dinyatakan oleh William Irwin Thomson, bahwa spiritualitas bukan agama. Namun demikian ia tidak dapat dilepaskan dari nilai-nilai keagamaan. Maksudnya ada titik singgung antara spiritualitas dan agama. Spiritualitas bisa saja tercermin dari kehidupan rohani penganut ideologi seperti agnotisme, skeptisisme ataupun atheisme, misalnya. Dengan demikian mereka bisa saja mengatakan bahwa spiritualitas dalam atheisme. Nilai-nilai ideologis yang dianggapnya benar. Namun sebagai manusia, bagaimanapun manusia tidak dapat atau tidak mampu mengelak dari nilai-nilai kodrati sebagai manusia.

Sistem nilai hubungan terkait dengan kebenaran. Dalam pandangan Yakob Sumardjo: "begitu manusia menemukan kesadarannya, dia menuntut dirinya untuk hidup dalam apa yang disebutnya kebenarannya. Apa yang benar bagi seseorang adalah apa yang sesuai dengan kesadarannya, yang disetujuinya, yang dianggapnya baik, yang dianggapnya punya nilai, yang dapat dijadikan pegangan dalam bertindak." Kebenaran menurut Yakob Sumardjo adalah sesuatu yang kita mengatakan yang kepadanya (Yakob Sumardjo, 2000: 3). Selanjutnya penjelasan oleh Yakob Sumardjo dalam sejarah manusia dikenal melalui lembaga kebenaran yang kita kenal sebagai agama, ilmu, filsafat, dan seni. Melalui keempat lembaga itulah manusia mencari dan menemukan kebenarannya sendiri. Tetapi, karena kebenaran itu abadi maka kebenaran sejati dalam setiap lembaga itu akhirnya bermuara juga 
pada kebenaran itu. Hegel menyebutkan bahwa seni, agama, dan filsafat merupakan manifestasi manusia dari roh absolut (Henry Aiken, 2000: 90). Makna suatu kebenaran terletak pada kebebasan dan kesadaran, serta menjadi tahu tentang alam semesta ini (Murtadha Muthahari, 1998: 55). Kebebasan dalam pandangan Hegel adalah kemampuan untuk merealisasikan pada tiap diri. Diri itu bukanlah ego murni, secara konkret ia adalah personalitas yang memiliki kecenderungan dan kapasitas yang pasti. Dalam pandangan Nurcholish Madjid, aspek-aspek kebebasan dalam kaitan dengan pemahaman kejadian alam semesta tak dapat dilepaskan dari aspek historis penciptaan manusia itu sendiri.

Menurut Nurcholish Madjid, kemampuan untuk memahami alam semesta manusia telah menjadikan anugrah dari Tuhan dalam alam primordial, yakni ketika Adam diciptakan. Anugerah ini menjadikan Adam mampu menerima pengajaran dari Tuhan tentang nama-nama seluruhnya (al-asma kullaha) dan dengan begitu ia menyandang tugas suci sebagai khalifah Tuhan. Dengan akal, sosok Adam menembus gejala-gejala lahiriah keadaan sekelilingnya, dan melalui mata hati (bashirah) ia mencapai hikmah kearifan (Nurcholish Madjid, 2002: 28). Diakui atau tidak, manusia hakikatnya adalah makhluk ciptaan. Menurut Murtadha Muthahari, Allah telah menciptakan manusia dalam keadaan tertentu, yang di dalamnya terdapat kekhususan-khususan yang ditempatkan oleh Allah dalam dirinya saat dia diciptakan, dan keadaan itulah yang menjadi fitrahnya (Murtadha Muthahari, 1998: 60). Pandangan organisme ontologi yang dipengaruhi oleh paham teologisme menyatakan manusia itu merupakan makhluk refleksi keilahian (Suparlan Suhartono, 2005: 36).

Refleksi keilahian ini juga dijumpai dalam konsep sufisme $A l$ Hallaj dengan menyakini dalam diri manusia ada natur ketuhanan yang disebut labut (Muniron, 1999: 18). Kajian ahli psikologi atau syaraf Michael Persinger telah menemukan tentang eksistensi God Spot dalam otak manusia. Ini sudah built in sebagai pusat spiritual yang terletak diantara jaringan otak dan syaraf (Ayi Ginandjar Agustian, 2001: xvii). Dengan demikian nilai-nilai spiritualitas yang terefleksi dalam kehidupan rohani manusia siapapun tidak mungkin dilepaskan dari eksistensi God Spot sebagai pusat spiritual dimaksud. Dalam konsep ajaran Islam nilai-nilai moral itu disebut akhlak yang baik atau busn al-khulq (Murtadha Muthahari, 2000: 55). Pemahaman 
ini menunjukkan bahwa sebenarnya spiritualitas adalah potensi batini manusia. Sebagai potensi yang memberikan dorongan bagi manusia untuk melakukan kebajikan. Dalam agama Hindu, misalnya spiritualitas itu terlukis dari pernyataan Swami Vivekanda. Ia mengatakan bahwa jika seseorang telah mengenal Tuhan wajahnya, suaranya, dan rupanya berubah. Ia menjadi berkat, kesukaan untuk umat manusia (Franz Dahler dan Eka Budianta, 2000: 38).

Selanjutnya dalam nilai-nilai ajaran agama Kristen kondisi itu dilukiskan sebagai Yesus menjelmakan sekaligus cinta Allah kepada kita dan martabat luhru dari manusia yang paling hina sekalipun. Katanya segala sesuatu yang kamu lakukan untuk salah seorang dariku yang paling hina ini, kamu telah melakukannya untukku. Inti hakiki agama kristen Allah mencintai kita, Dia menerima kita sebagaimana adanya.

\section{Simpulan}

Dari penjelasan diatas dapat disimpulkan bahwa Manusia merupakan makhluk yang rumit dan misterius. Untuk memahami manusia dibutuhkan penjelasan dan interpretasi yang lebih banyak dibandingkan dengan yang dibutuhkan oleh selain manusia. Sebenarnya spiritualitas sebagai potensi batini manusia. Sebagai potensi yang memberikan dorongan bagi manusia untuk melakukan kebajikan. 


\section{DAFTAR PUSTAKA}

Agustian, Ari Ginandjar.2001. ESQ : Rahasia Sukses Membangun Kecerdasan Emosi dan Spiritual Berdasarkan 6 Rukun Iman dan 5 Rukun Islam, Jakarta: Arga.

Aiken, Henry.2000. Abad Ideologi, terj. Sigit Djatmiko.Yogyakarta: Bentang Budaya.

Dahler, Franz dan Eka Budianta.2000.Pijar Peradaban Manusia: Denyut Harapan Evolusi. Jakarta: Kanisius.

Fromm, Erich.1988. To Have Or To Be? New York Hagerstown, San Fransisco, London.

Madjid, Nurcholish. 2000. Kehampaan Spiritual Masyarakat Modern: Respon dan Transformasi Nilai-Nilai Islam Menuju Masyarakat Madani. Jakarta: Media Cita.

Muthahari, Murtadha.1998. Fitrah. Terj. Jakarta: Lentera.

Muniron.1999. Pandangan Al-Ghazali Tentang Ijtihad dan Hulul, Jurnal pemikiran Islam paramadina, Volume I, Nomor 2.

Nottingham, Elizabeth. 1985. Agama dan Masyarakat: Suatu Pengantar Sosiologi Agama, terj. Abdul Muis Naharong. Jakarta: Rajawali. 